\title{
Education, Conflict and Harmony in Book 1 of Plato's Laws
}

\author{
Diego García Rincón
}

Book 1 of Plato's Laws, and particularly the image of the puppet introduced near its end, has been traditionally interpreted as presenting the moral psychology model that underlies the educational system delineated by the Athenian Stranger, which construes virtue as consonance between the non-rational and the rational elements of the soul. But a different and competing conception of virtue looms large in Laws 1, virtue as victory of the best part of the soul in psychic conflict. This paper argues that the Athenian's conception of education as the correct conformation of originally conflicting psychic forces requires the simultaneous presence of the harmony and the conflict models of virtue in Laws 1. Education is in turn defined by calculation, the rational activity which persuasively leads the conflicting non-rational forces towards a consonant reciprocal rapport. By strategically developing his understanding of education and calculation in Laws 1, the Athenian shows how the harmony model of virtue overcomes the conflict model, while at the same time recognising that there is some truth to the conflict model after all and integrating it within the harmony model.

\section{Introduction}

Book 1 of Plato's Laws has been the object of much detailed scholarly attention in the last years. ${ }^{1}$ Spousing what could be termed the 'traditionalist' reading, most commentators agree that the image of the puppet at the end of Book 1 (644d-45d) lays out the moral psychology for the construal of virtue as concord or consonance, the model of virtue which underlies the educational project that the Athenian Stranger develops in Books 1, 2 and $7^{2}$, and some even extend the relevance of the image's moral psychology

\footnotetext{
${ }^{1}$ I would like to thank Dr. Alfonso Flórez for his contribution to the development of many of the views expressed here, and Dr. Fabio Morales for his valuable and detailed comments on earlier drafts of this paper.

${ }^{2}$ So C. Gaudin, 'Humanisation de la Marionette. Plat. Leg. I 644c-645d; VII 803c-804c', Elenchos 23 (2002) 271-95, 273; E. Jouët-Pastré, Le jeu et le sérieux dans les Lois de Platon (Sankt Augustin: Academia Verlag, 2006) 42; C. Zuckert, Plato's Philosophers: The Coherence of the Dialogues (Chicago: University of Chicago Press, 2009) 69ff.; D. Frede, 'Puppets on strings: Moral Psychology in Laws Books 1 and 2', in C. Bobonich, ed., Plato's Laws: A Critical Guide (Cambridge: Cambridge University Press, 2010) 108-26, 117; M. Schofield, 'Plato's
} 
to the whole work. ${ }^{3}$ The main reason for this is that the Athenian presents the puppet image shortly after the first detailed discussion on the nature of education $(641 \mathrm{e}-44 \mathrm{~b})$, and its appearance is closely followed by the elaboration of concrete educational institutions, in which the image of the puppet plays a prominent role. As Susan SauvéMeyer has recently shown ${ }^{4}$, however, in Book 1 of the Laws there is also much talk of virtue as victory in psychic and political conflict, a talk that the Athenian carries on for long after he has openly expressed his discontent with such an understanding of virtue. The consideration of conflict is indeed so persistent that, against the traditionalist reading, victory in conflict and not the psychic consonance which is the aim of education could be construed as the predominant model of virtue in Book 1. So 'readers of the dialogue,' Sauvé-Meyer says, 'must face the question of why the Athenian continues to appeal to the conflict model even though he does not endorse it and has discredited it' 5

Taking my cue from Sauvé-Meyer's distinction of the 'harmony' ${ }^{6}$ and the 'conflict' models of virtue, I would like to offer a traditionalist reading of Book 1 of the Laws which takes into account the role that conflict plays in its moral psychology. The kernel of my argument lies in the interpretation of the Athenian's conception of education

Marionette', Rhizomata 4/2 (2016) 128-53, 132; and most recently J. Annas, Virtue and law in Plato and Beyond (Oxford: Oxford University Press, 2017) 86. H. Fossheim instead maintains that the aim of the image is 'not to function as a model for moral psychology, but to give an exhortative picture of how we should see ourselves as weak and far from the gods in qualities' ('The Prooimia, Types of Motivation, and Moral Psychology', in C. Horn, comp., Platon: Gesetze - Nomoi [Sankt Agustin: Academia Verlag, 2013] 87-104, 92). As we will see, given the central role that the terminology of the puppet plays in the discussion of education in Books 1 and 2, it is hard to defend that the image has such a limited scope.

${ }^{3}$ Cf. J. Wilburn, 'Akrasia and Self-Rule in Plato's Laws', Oxford Studies in Ancient Philosophy 43 (2012) 25-53, 27, and more recently J. A. Giménez Salinas, 'La psicología moral de la marioneta. Conflicto y acuerdo en las Leyes de Platón', Ideas y Valores 68.171 (2019) 137-159, 139.

${ }^{4}$ See S. Sauvé-Meyer, 'Self-Mastery and Self-Rule in Plato's Laws', in D. Brink, S. SauvéMeyer, and C. Shields, eds., Virtue, Happiness, Knowledge: Themes from the Work of Gail Fine and Terence Irwin (Oxford: Oxford University Press, 2018) 97-109, 99 ff. The expressions 'conflict model for virtue' and 'harmony model for virtue' are taken from Sauvé-Meyer.

5 'Self-Mastery', 99.

${ }^{6}$ It must be noted that the term actually used by the Athenian to describe the virtuous state of the

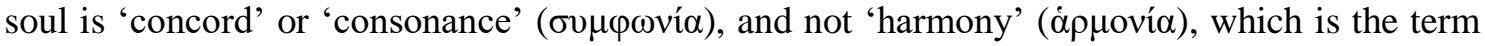
Socrates uses in the Republic to describe moderation (cf. 431e; note however the expression

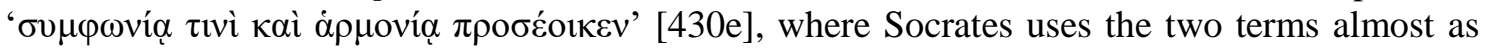
synonyms). In order to avoid ambiguity (see n. 6), I follow Sauvé-Meyer in her general designation of the Athenian's virtue model as the 'harmony' model, although it would be more literal to speak of the 'consonance' model. 
as the process by which struggling psychic forces are brought to consonance with each other. The Athenian's conception of education and the moral psychology that he offers to support it explain, I suggest, why both the 'conflict' and the 'harmony' models of virtue must be present in Book 1 in general and in the image of the puppet in particular. This approach presupposes that, as the traditionalist reading maintains, the puppet's moral psychology can only be rightly interpreted by explaining how it fits into the Athenian's broader account of education.

I will start by calling attention upon the various ways in which the Athenian prompts us to recognise political and psychic conflict as the starting point from which consonance is produced in the city and the soul by means of education. This will allow in the second section for a more precise formulation of the two models of virtue, in which conflict and consonance/harmony are differentiated qua states of the soul, on the one hand, and qua processes of acquisition of virtue containing multiple soul-states, on the other. $^{7}$ This distinction will help untangle some of the difficulties raised by Sauvé-Meyer, so that the relation between the two models can be precisely formulated as the integration, within the harmony model of virtue, of some of the central theses of the conflict model.

To support his understanding of education the Athenian presents a moral psychology that explains how the state of conflict arises among the psychic forces and how the process of their correct conformation through education and legislation works. I turn to this in the third section. As we will see, the initial sketch of moral psychology (644b-d) establishes rational calculation as 'the best part in us', the part that ought to be victorious in psychic conflict but which, paradoxically, is not depicted by the Athenian as partaking in it in the same sense as the non-rational forces. The reason for this qualified exclusion of calculation from psychic conflict will become clear with the analysis of the image of the puppet in the fourth section. Calculation is a 'pull' in the soul, but its 'soft and forceless' nature makes it impossible for it to forcefully partake in conflict and thus overcome the non-rational elements of the soul. It is involved in the conflict through its association with some non-rational elements, the 'helpers' of calculation.

The argumentative strategy of the Athenian in Book 1 will thus become clear. By exposing his understanding of the process of education, perfected with the development of calculation in the citizen, he shows that the 'victory' of 'the best part in us' is not the

\footnotetext{
${ }^{7}$ Anticipating the distinction, the term 'harmony' will refer exclusively to the Athenian's model of virtue understood as a process, while the term 'consonance' is reserved for the psychic state at which the harmony model of virtue aims.
} 
kind of forceful victory required by the conflict model of virtue, since calculation isn't capable of exercising force. Calculation by its very nature rather aims at psychic consonance, a state in which no part of the soul vanquishes the others. However, the Athenian recognises that this process does begin with psychic conflict. In this way, I submit, the Athenian manages to overcome the conflict model of virtue while integrating its share of truth within the harmony model. The traditionalist reading of the puppet image thus prevails, but it has to grant that the psychic state of conflict is indeed the starting point for any consonance-oriented form of education.

\section{Education and Conflict}

The Athenian first defines education as the guidance 'towards human goodness

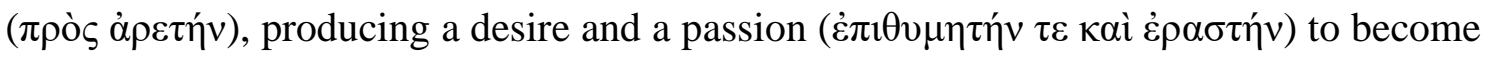
a complete citizen, one who knows how to rule and be ruled in accordance with justice' (643e). ${ }^{8}$ As has been often noted, although it certainly implies a link with normative beliefs, education as described here operates at the non-rational level of the citizen's desires and passions. ${ }^{9}$ Its first stage consists in the correct orientation of these nonrational forces through play, by means of which children are led towards desire and love

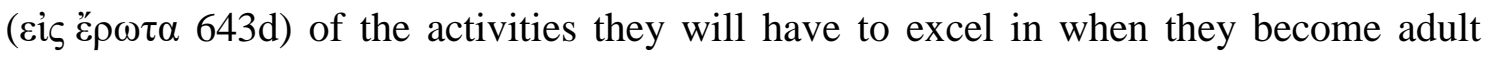
citizens. This is stressed again by the Athenian in a later definition of education that enumerates more fully the non-rational forces that are to be oriented. The aim is that 'pleasure, friendship, pain, and hatred arise in the proper way (ỏ $\rho \tilde{\omega} \varsigma)$ in the souls of

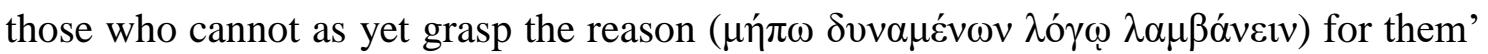
(653b). The correct way conformation of the non-rational will be showed to consist in a kind of consonance or agreement between the various forces that constitute it, and between it and the rational faculties. These provisional definitions will be further expanded with a more exhaustive delineation of the non-rational elements of the soul, as well as with the addition of the rational development needed to produce a fully formed citizen. But it should be noted that in every attempt at definition made by the Athenian

\footnotetext{
${ }^{8}$ The translation given throughout is that of T. Griffith, trans., and M. Schofield, ed., Plato: The Laws (Cambridge: Cambridge University Press, 2016).

${ }^{9}$ For a representative example, see G. Klosko, The Development of Plato's Political Theory (Oxford: Oxford University Press, 2006) 219.
} 
the overall aim remains one and the same, namely to produce consonance among the various elements in the soul.

The 'harmony' model of virtue on which this understanding of education is based is spelled out by the Athenian at the beginning of Book 2: 'if, when they do grasp the

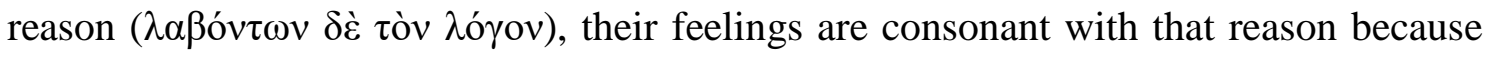
they have been correctly trained by the appropriate habits, then this consonance is in

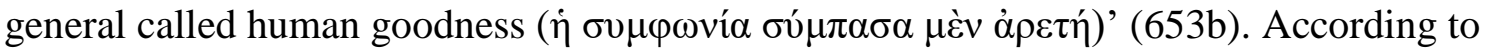
this, the virtuous state of the soul is one in which there exists consonance, agreement or concord between the various psychic elements. This formulation of the harmony model of virtue at the beginning of Book 2 represents the climax of a series of critical remarks that the Athenian elaborates throughout Book 1 in response to the Dorian conception of virtue, introduced by Clinias almost at the beginning of the dialogue. This Dorian conflict model of virtue is based on the assumption that 'there is always, for all of us, a lifelong and continuous state of war ( $\pi$ ó $\lambda \varepsilon \mu \rho \varsigma)$ against all others cities' $(625 \mathrm{e})$. When pushed by the Athenian's questions, Clinias goes on to add that this state of war extends to households against each other, and to individuals against each other and even against themselves: 'all are the enemies of all, in the public and private sphere,' and 'every individual is enemy to himself' (626d). Virtue thus consists in the capacity of achieving victory over 'oneself' (be it a city, a household or an individual), that is, achieving the victory of the best part of oneself over the worse parts $(627 \mathrm{a}-\mathrm{c}){ }^{10}$

On the face of it, the two models of virtue seem to be completely at odds with each other. One presents a conflictive political or psychic ensemble in which the best part must vanquish the others, the other a consonant ensemble in which conflict doesn't arise. Surely, one could argue that the two models are simply put forth by different characters of the dialogue, so that in principle there must not necessarily be any link between them. However, this does not answer the question of why Plato presents the two models as competing in Book 1 of the Laws, only to make the conflict model disappear from Book 2 onwards. From the perspective of the argumentative structure of the dialogue, this raises the question about the relation in which each model stands to one another. Can they be somehow integrated, as I would like to suggest, or is the divide between them final? Two

\footnotetext{
${ }^{10}$ This later bit is a crucial step in the argumentative structure of Book 1, and is analysed well by C. Jorgenson, The Embodied Soul in Plato's Later Thought (Cambridge: Cambridge University Press, 2018) 26-7.
} 
main positions have been recently defended: on the one hand, Malcolm Schofield argues for a total defeat of the conflict model by the harmony model, while Sauvé-Meyer defends the irreducible opposition and persistence of both models. ${ }^{11}$ The position I delineate here lies somewhat at the midpoint between these two poles. It seems to me that the harmony model ultimately prevails, but that the truth in the Dorian conflict model is nevertheless recognised by the Athenian, in the sense that political and psychic conflict become integrated in a complex way within the harmony model of virtue. I will now start to substantiate this claim by showing that, according to the Athenian, political and psychic consonance are states attained through the appeasement of an initial state of conflict.

Just after Clinias' initial formulation of the conflict model, and in order to criticise it, the Athenian presents an analogy that offers key insight into the relation between conflict and consonance as they arise in social ensembles. He invites his interlocutors to imagine a family in which most of the brothers were born bad and only a small part of them good, a family that would inevitably enter into conflict with itself. In such a scenario, a judge who wanted to resolve the conflict would find himself before three alternative solutions:

Which would be better - the judge who destroyed those of them who were bad, and told the better ones to be their own rulers, or the one who told the good ones to be rulers, but allowed the worse to live, having made them willing to be ruled? And presumably, with our eye on excellence

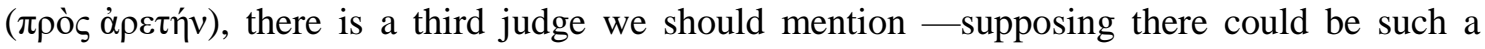
judge - the one who would be able to take this single family which is at odds with itself

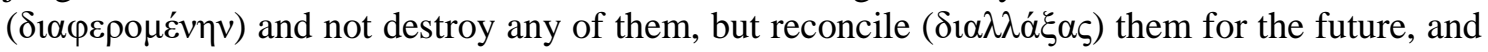
give them laws to keep them on good terms with one another. (627d-28a)

The first alternative entails the complete victory of the good brothers by means of violence and could be seen as the ideal scenario according to the Dorian war-oriented legislations, although it could be argued that the destruction of a faction is hardly a 'solution' for a conflict. As Sauvé-Meyer notes, the second alternative is difficult to differentiate from the third one, mainly because the bad brothers submit to the rule of the

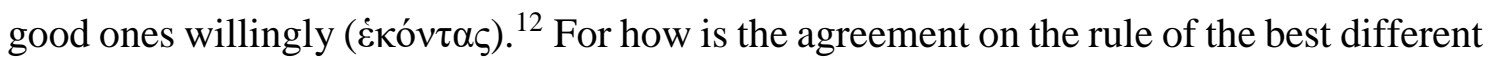
from the peaceful state that, as we will see, the Athenian sees as characteristic of the best social ensemble? Be that as it may, the Athenian openly endorses the third solution, where

\footnotetext{
${ }^{11}$ Cf. Schofield, 'Plato's Marionette', 147-9, and Sauvé-Meyer, 'Self-Mastery', 108.

12 'Self-Mastery', 101
} 
no use of violence is made and the friendly coexistence of the brothers is achieved by means of legislation.

After Clinias admits that the third is indeed the best solution, the Athenian goes on to draw the political conclusion that, in a city as well in the hypothetical family, 'what is best is not conflict, nor civil war (things we pray there will never be a need for), but rather peace - yes, and amity — with one another' $(628 \mathrm{c}-\mathrm{d})$. This means that the ultimate aim of the legislation is not victory in war, as the Dorians would have it, but peaceful relations of the city with other cities and with itself. The best legislator is consequently

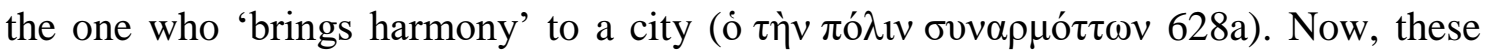
remarks could be interpreted as saying that what is preferable is that conflict was never produced in the first place in the community, and that all along political consonance prevailed. But this cannot be the moral of the story of the brothers, I take it, for the Athenian has clearly presented the third alternative as one possible outcome for their initial conflict. As in the first two cases, in the third one the judge takes a family which is

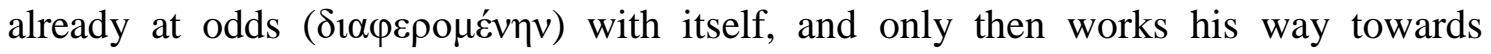
reconciling ( $\delta 1 \alpha \lambda \lambda \alpha \dot{\xi} \alpha \varsigma)$ it through legislation. Moreover, the very nature of the law enacted to resolve the conflict implies that it can be transgressed, and that the consonance that resulted from legislation can be lost. ${ }^{13}$ Conflict would thus reappear in the community, and consonance would have to be regained. The upshot is that, even if the sociopolitical state of consonance does by definition consist in the absence of conflict, it is necessarily produced from an initial state of conflict and is always in danger of falling into conflict again.

The mechanism for resolution of conflict aiming at reconciliation and virtue

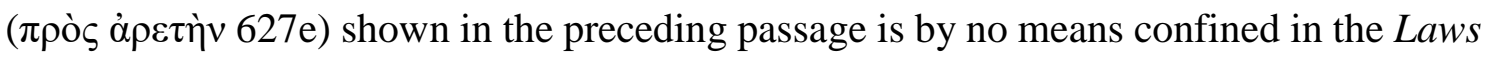
to the political sphere. The initial conflict of the parts which are to be brought to consonance with one another, as well as the danger of falling back into conflict after consonance has been achieved, are both constitutive moments of the process of education exposed by the Athenian throughout Books 1 and 2. Initially, it could seem that the Athenian's education has no room for psychic conflict, because its moral psychology rests entirely on the harmony model of virtue. The aim at consonance indeed underlies the definition of education as a direction of the citizen's desires and passions towards virtue

\footnotetext{
${ }^{13}$ This is the Athenian's justification for the delineation of the Laws' penal code in Book 9 (853a854a). Cf. M. Schofield, 'The Laws' Two Projects', in C. Bobonich, ed., Plato's Laws: A Critical Guide (Cambridge: Cambridge University Press, 2010) 12-28, $23-4$.
} 
(643e), for the fundamental goal is to form the non-rational in such a way that it doesn't conflict with the rational once it develops (653b). It is nevertheless also true that the conformation of these non-rational elements is a process that starts from an initial conflict. This transpires in Book 1 by way of the language the Athenian uses to describe a concrete educational institution, the directed symposia which at first sight appear alarming to his Dorian interlocutors (see 638c-42a), and which become the main theme of the whole closing section of Book $1(645 \mathrm{c}-50 \mathrm{~b})$. For reasons that will be discussed shortly, the Athenian depicts these educational symposia as a kind of Dorian war-training wherein a battle against pleasures is produced and in which the young citizen strives to achieve victory. 'Don't we have to bring him face to face with shamelessness,' the Athenian asks Clinias (647c), 'train him to fight against it, and in this way give him

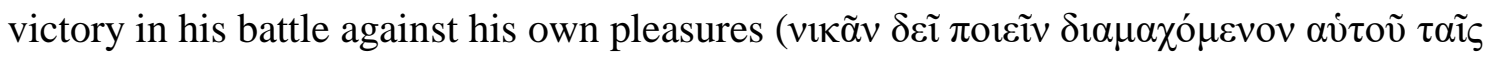

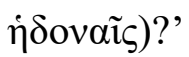

That the soul of the young citizen is torn by conflict is proved by the fact that it is said to engage in battle against his own pleasures, thus recalling Clinias' earlier claim that 'every individual is enemy to himself' (626d). However, the scope of the symposia is not limited to enabling the young citizen to be victorious in this 'battle' against pleasure, a point made by the Athenian in Book 2, where the institution appears embedded within his broader considerations on consonance-oriented musical education (cf. 671b-72a). The ultimate aim is that the plastic state of soul produced by wine in the young citizens

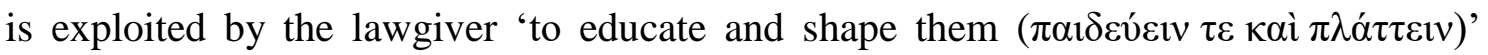
(671c), that is to say, to instil consonance among the formerly conflicting psychic elements. ${ }^{14}$ Once the non-rational elements become correctly trained, conflict is at least temporarily absent. This explains why, although the institution is partially modelled after Dorian war-oriented practices, its proper scope is described by the Athenian as a meeting 'of friends, gathering in peacetime (cipńvฺ) to share with friends in mutual goodwill (

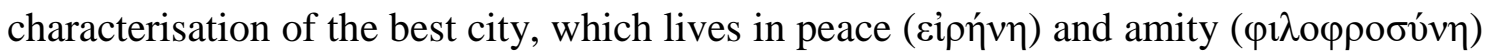
with itself and with others $(628 \mathrm{c}-\mathrm{d})$.

If this is right, an important part of the citizen's consonance-oriented education operates from an initial state of psychic conflict. The Athenian thus brings to our attention

\footnotetext{
${ }^{14}$ Giménez, 'La psicología moral', 155, is thus right in noting that even though moderation is acquired through a training analogous to that needed to produce courage, it doesn't consist in a strife among opposing psychic forces.
} 
the basic fact that the need for instilling consonance in the soul can only arise from an original lack of such consonance. This allows to draw a parallel between what I take to be the sociopolitical and the individual psychological dimensions of the harmony model of virtue. ${ }^{15}$ Inasmuch as it presents a whole in disagreement with itself, the initial strife of the brothers is analogous to the initial conflict in the young citizen's soul. Furthermore, the peaceful state that arises through the reconciliation of the brothers' strife by means of legislation is analogous to the consonance aimed at by means of the educational symposia. The Athenian suggests this connection between education and law by saying that the person in charge of educating the souls of drunken young citizens is the legislator himself, who enacts 'laws to govern drinking parties' (671c), thus operating in a very analogous way to that in which the third and best judge reconciles the struggling brothers with one another through legislation. In both cases, then, the achievement of consonance presupposes an initial conflict in the ensemble which is to be brought to agreement with itself.

Moreover, in many cases the consonant psychic state achieved through education is bound to be lost. That the conflict thus produced concerns education is proved by the fact that the Athenian addresses this issue in the same passage in which he formulates the harmony model of virtue: 'this education that consists in a proper upbringing of pleasures and pains - it's only human for this to lose its effect and be in large measure destroyed over the course of a lifetime' (653c). The soul 'falls out of tune' ( $\chi \alpha \lambda \tilde{\alpha} \tau \alpha 1)$, so that the need appears for the festivals that structure the social life of Magnesia, the Athenian's city in speech, educational institutions which guarantee that no citizen ever ceases to be under the (re)formative influence of the music and the laws (653c-54a). Education thus becomes a lifelong affair, and for our present purposes the relevant consequence is that the consonance at which it aims is a state of the soul which can neither be produced without presupposing an initial conflict nor avoid future conflict altogether once it has been produced. ${ }^{16}$

\footnotetext{
${ }^{15}$ The distinction is also made by Sauvé-Meyer, who talks of the political, familial and individual 'cases' of each model of virtue (cf. 'Self-Mastery', 100, 104-5).

${ }^{16}$ Regarding the psychological side of the issue, E. Belfiore, 'Wine and the Catharsis of Emotions in Plato's Laws', Classical Quarterly 36/2 (1986) 421-37, at 428-33, argues that the virtuous soul must be conceived of as containing in itself forces against which it must fight, and similarly C. Bobonich, Plato's Utopia Recast: His Later Ethics and Politics (Oxford: Clarendon Press, 2002) 289, claims that a virtuous individual could still have some conflicting non-rational elements within. I agree with them on the importance of maintaining conflict on the horizon after
} 


\section{The integration of conflict within the harmony model of virtue}

\section{Reformulating the Two Models}

But is it not contradictory to claim that harmony allows for conflict? Surely, the state of a consonant soul or a peaceful city does by definition exclude any sort of conflict. This suggests another form of relation between conflict and harmony/consonance. Because in my account the harmony model of virtue recognises the existence of conflict and the need for its resolution, the fundamental difference between it and the conflict model seems to me to lie in the modality of the resolution of conflict in each model. I would like to make this point by offering a more precise delineation of the two models of virtue identified by Sauvé-Meyer. There seems to be an ambiguity in the use of the terms 'conflict' and 'harmony'. In the strict sense, these terms refer to states or conditions of the soul: one in which the psychic elements are at odds with each other, another one where they agree; I have termed the latter 'consonance' to differentiate it from the 'harmony' model. In a general sense, the terms refer instead to models of virtue which depict a processual understanding of the states of the soul and of their dynamic reciprocal relationships and developments. According to this, the two models of virtue can be reformulated as follows:

1. The conflict model of virtue designates a process in which the state of conflict is subdued through the use of some kind of forceful compulsion that results in the victory of 'the best part' in the ensemble in question. As Clinias indicates, this response to the state of conflict doesn't really eliminate the enmity between the parts (which is made to be natural and perpetual), but rather subdues it temporarily.

2. The harmony model of virtue designates a process in which the state of conflict among the parts is resolved by means of legislation and education, activities aiming at producing a state of consonance among the originally conflicting parts. Once achieved, this state of consonance can be lost, so that within the process designated by the harmony model we find a dynamic relation between the states of conflict and consonance. ${ }^{17}$

The difference between the two models, their respective modalities of response to conflict, is a not minor one. In trying to appease the initial state of conflict, the way of

virtue has been achieved, but I think that consonance as conceived by the Athenian is a state in which conflict is indeed completely absent, even if only temporarily so (so also Sauvé-Meyer, 'Self-Mastery', 103-4).

${ }^{17}$ Giménez, 'La psicología moral', 145, has recently proposed a similar distinction, although it is limited to the contrast between the process of acquisition of moderation and the moderate psychic state resulting from that process. 
reconciliation advocated by the Athenian starkly contradicts Clinias' grim thesis that

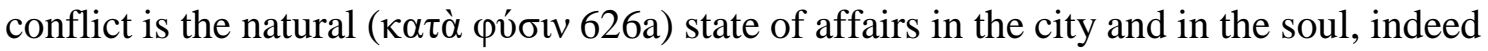
extending throughout the whole of life (cf. 625e). According to the Athenian conflict is neither a necessary nor a natural state, but it is nevertheless the departure point from which consonance is produced.

This reformulation of the two models of virtue helps understand the Athenian's argumentative strategy in Book 1. Because consonance is generally born out of different forms of conflict, the Athenian can partially agree with Clinias' thesis of all-pervasive conflict while at the same time introducing progressively his 'harmony' model for conflict resolution. He does this first through his analogy of the strife among the brothers $(627 \mathrm{~d}-$ $28 \mathrm{a})$, then through his remarks on the consonance-oriented nature of true education $(643 \mathrm{e}-\mathrm{d})$, and finally through the image of the puppet itself. It is therefore not the case that, in accepting conflict, the Athenian argues strategically for premises that he denies tout court, as Sauvé-Meyer maintains. ${ }^{18}$ The Athenian is prepared to accept Clinias' conflict thesis in a reduced, less radical version in which it is subordinated to achieving a state of consonance. Albeit in a heavily qualified way, one of the main tenets of the conflict model of virtue thus becomes integrated in the harmony model.

\section{Persuading the Dorians: the Athenian's Strategy}

There is one central difficulty regarding the Athenian's argumentative strategy. After he first criticises Clinias' conflict model through his analogy of the strife of the brothers, he is quick to conclude that for a city what is best is not war or faction, but rather peace and amity (628c-d). As Sauvé-Meyer points out, however, in this passage the Athenian fails to draw explicitly the analogous conclusion regarding the superiority of psychic consonance over victory in psychic conflict. ${ }^{19}$ He presents the harmony model of virtue in its political version, but not in its psychological version. To be sure, the Athenian does remark that they are dealing with 'a question of happiness for a city or an individual

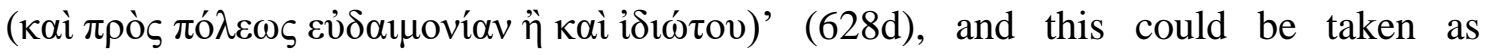
implying that he holds his conclusion to be valid also in the psychological sphere. Similar formulations are present throughout Book 1 regarding related themes such as the

\footnotetext{
18 'Self-Mastery', 99.

19 'Self-Mastery', $102 \mathrm{ff}$.
} 
centrality for legislation of pleasures and pains 'whether in cities or in the behaviour of individuals' (636d), or the benefit that correctly supervised symposia represent for 'private individuals or the city' (641b). Significantly, the formulation is also echoed in the puppet image itself, whose moral is made to apply to 'the city and the individual' (645b). All this suggests that, although the analogy between the city and the individual is not explicitly stated by the Athenian as it is by Socrates in the Republic (441e-44b), it remains operative in the Laws, as it certainly is in the Athenian's initial questioning of Clinias at 626b-d, where he makes Clinias conclude that what is valid for the state of war among cities is also valid among households and among individuals.

The problem nevertheless remains that the Athenian does not explicitly present the full psychological formulation of the harmony model of virtue until the beginning of Book 2 (653b). This raises the question of why the Athenian continues to use the language of the conflict model of virtue after he has openly expressed his discontent with its political version. The issue becomes even more pressing when we arrive at the puppet image, where the language of conflict is so pervasive that Sauvé-Meyer interprets the image as addressing exclusively the central problem of the conflict model of virtue, namely how the best part of an individual can achieve victory over his worse parts. ${ }^{20}$ Why indeed does the Athenian argue in this way?

To answer this question, other important features of the argumentative structure of Book 1 must be noted. While Sauvé-Meyer is right in emphasising that the Athenian introduces the image of the puppet by saying that it contributes to the understanding of self-mastery (644b), it is also true that the long stretch of text that goes from $641 \mathrm{~b}$ to the puppet image is dominated by the theme of 'education as a whole ( $\pi \alpha 1 \delta \varepsilon i ́ \alpha \varsigma \tilde{\eta} \varsigma \pi \alpha ́ \sigma \eta \varsigma)$ ' (642a). Moreover, the closing section of Book 1 (645c-650b), which immediately follows the puppet image, is concerned with laying the foundations for a concrete educational institution, the symposia which will be extensively addressed in Book 2 . The fact that the image of the puppet is thus surrounded by an ongoing disquisition on education indicates that the image itself must contribute to this subject, which the Athenian significantly puts at the basis of all the other subjects presently under discussion (cf. 642a). Therefore, the scope of the image cannot be limited to formulating the psychological version of the conflict model of virtue, as Sauvé-Meyer maintains. As we will see in the fourth section, this is explicitly confirmed by the Athenian at the end of the puppet image (cf. 645c). The

\footnotetext{
20 'Self-Mastery', 106.
} 
question thus becomes not why the Athenian continues to use the language of the conflict model after having criticised it, but why he uses the language of both models of virtue at the same time throughout Book 1 and embeds both of them in the image of the puppet.

I take this duplicity of the Athenian's language as an essential feature of the argumentative strategy he deploys to persuade his Dorian interlocutors that the harmony model of virtue is superior not only in its political version, but also in the psychological one. He introduces this strategy as a methodological proposal after his first criticism to the political version of the conflict model. The Athenian claims that, as any good lawgiver, the Cretan and Spartan lawgivers cannot have legislated only with an eye to

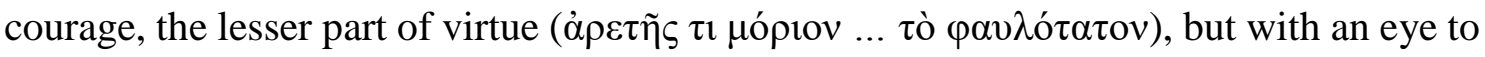
virtue as a whole ( $\pi \tilde{\alpha} \sigma \alpha \nu \dot{\alpha} \rho \varepsilon \tau \eta ́ v)$ (630e). The aim of the discussion on laws should consequently be the whole of virtue, including (in decreasing order of importance) wisdom, temperance, justice and courage (631c-d; cf. 630b). Because his two interlocutors are mostly familiar with Dorian legislations in which courage plays a prominent role, however, he proposes to examine the whole of virtue starting from courage, the lesser part, and taking it as a paradigm ( $\pi \alpha \rho \alpha ́ \delta \varepsilon 1 \gamma \mu \alpha \theta \varepsilon \dot{\varepsilon} \mu \varepsilon v o 1)$ for the other three virtues, so that in this way they examine 'virtue as a whole' (632e).

The Athenian's insistence on the need for examining the whole of virtue reveals the strategy behind his methodological proposal. In a closely preceding passage, he claimed that the better individual is not the one who is courageous in external war, but the one who is loyal in faction thanks to the possession of "virtue in its entirety

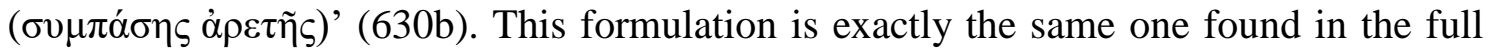
appearance of the harmony model of virtue at the beginning of Book 2, where psychic $\sigma u \mu \varphi \omega v i ́ \alpha$ is presented as 'virtue in its entirety ( $\sigma u ́ \mu \pi \alpha \sigma \alpha \mu \dot{\varepsilon} v \alpha \dot{\alpha} \rho \varepsilon \tau \eta ́) '(653 b)$. The passage at $630 \mathrm{~b}$ could thus be taken as the first, albeit cursory, appearance of the psychological version of the harmony model of virtue. ${ }^{21}$ But the Athenian doesn't develop this psychological formulation of the matter, and this is where his strategy becomes evident. Instead of immediately arguing for the superiority of the psychological version of the harmony model (as he did with the political version), he chooses to examine the entirety of virtue starting from courage, thus choosing as a paradigm precisely that virtue which

\footnotetext{
${ }^{21}$ The point is noted by Schofield: 'this is the Athenian's first statement of the conception of human goodness he will assume and articulate in different ways throughout the dialogue' (Plato, the Laws, 40 n. 15).
} 
he deems to be the 'lesser' of the four. As Julia Pfefferkorn puts it, 'courage is, in quite an ingenious manner, simultaneously devaluated and used as a 'model', ${ }^{22}$ This can only make sense in light of the Athenian's ongoing strategy to integrate conflict and courage within the harmony model of virtue, while persuading the Dorians that this operation is legitimate. ${ }^{23}$ The qualified integration of Clinias' all-pervasive conflict thesis within the harmony model of virtue is, I submit, one of the central features of this strategy.

The strategy requires that the Athenian models the moral psychology he presents to the Dorians in the puppet image after their war-oriented conception of virtue, although the image ultimately purports to clarify education and thus to illuminate the harmony model of virtue. Whether or not the Athenian manages to carry out this difficult project is open for discussion. I will try to argue that he does. Let us turn then to the initial sketch of moral psychology provided by the Athenian.

\section{The Constitution of the Individual Soul}

After his interlocutors accept the consonance-based definition of education and its political significance $(644 a-b)$, the Athenian recalls the earlier agreement that 'those

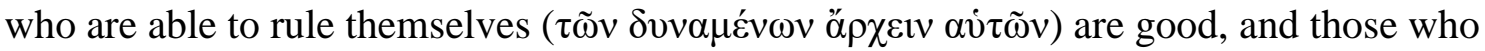
don't are bad' (644b). ${ }^{24}$ The agreement in question was produced when self-rule was

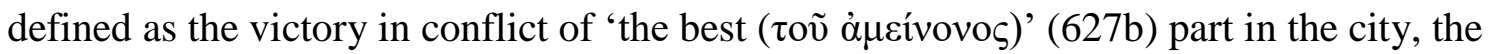
family and the individual. Now the precise nature of this 'best part' in the soul comes under examination, and the Athenian introduces an enumeration of the elements that constitute the individual soul. Each individual, he says, is a single entity 'possessing,

\footnotetext{
${ }^{22}$ J. Pfefferkorn, 'Shame and Virtue in Plato's Laws: Two Kinds of Fear and the Drunken Puppet', in L. Candiotto and O. Renault, eds., Emotions in Plato (Leiden/Boston: Brill, 2020) 252-269, 260.

${ }^{23}$ Along the same lines, Zuckert, Plato's Philosophers, interestingly reads Books 1 to 3 as an educational strategy to persuade Clinias and Megillus, the Athenian's 'students' (64 ff.), to accept his legislative proposals. Schofield, Plato, the Laws, 52 n. 31, also notes that in a passage preceding the discussion of education the Athenian takes a 'didactic stance' (cf. 640a).

${ }^{24}$ The Athenian signals the continuity between the themes of education and self-mastery by his passage from one to the other through the preposition kai (644b6); cf. M. Folch, The City and the Stage: Performance, Genre, and Gender in Plato's Laws (Oxford: Oxford University Press, 2015) 77. Schofield notices the coordination, noting that the enumeration of psychic elements that follows serves 'the broader agenda of education for virtue - and in the first instance for courage - to which the treatment of self-rule is designed to contribute' ('Plato's Marionette', 132).
} 
within himself, a pair of mindless and opposed ( $\dot{\varepsilon} v \alpha v \tau i ́ \omega)$ advisers - to which we give the names pleasure and pain' (644c). He continues:

And in addition to these two, there are also opinions about what is going to happen, to which we give the general name 'expectation', but the particular name 'fear' for expectation of pain, and

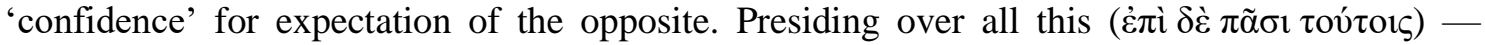

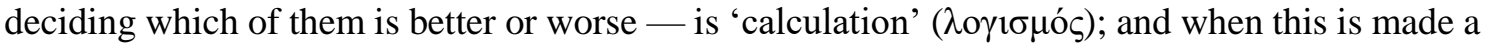

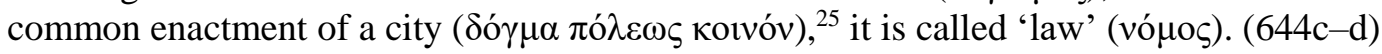

Shortly before this passage, the Athenian first defined education as the production in the citizen of desire and passion towards the rational principles of the political community (cf. 643e). As was noted, education thus defined requires the correct conformation of the non-rational elements of the soul. These elements are now explicitly named 'pleasure and pain', together with their respective anticipations, 'confidence and fear' ${ }^{26}$ The conflictive nature of this non-rational psychic sphere is brought to the fore

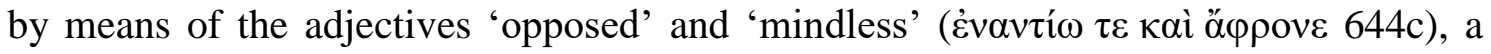
characterisation extended to the anticipations themselves, whose activity tends towards

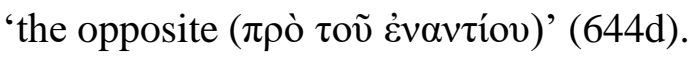

The Athenian continues his sketch with the addition of 'calculation', the activity by which the individual evaluates the inclinations of the non-rational forces. This

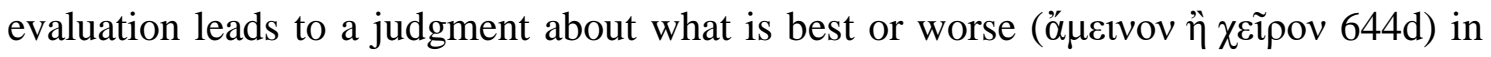
them. Calculation thus appears as a second, distinct level of activity operating over and referring to the first level of non-rational activity. This point is not uncontroversial. The translation accepted here construes the relation of calculation with the first level of nonrational activity as one of reflection and not as one of opposition. Sauvé-Meyer instead emphasises the presence of the conflict model of virtue in this passage by translating

\footnotetext{
${ }^{25}$ Here I follow Schofield, Plato, the Laws, $131 \mathrm{n}$. 5, in his modification of Griffith's version, which seems to miss the point with the less literal translation 'when this is enacted by the city as a whole'. The Athenian's point seems not to be that the whole city participates in the enactment of the law, but rather that once enacted the law becomes 'common (koinon)' for the city.

${ }^{26}$ It is generally agreed that the expression 'pleasures and pains' refers to the sphere of nonrational phenomena in the human soul. So Bobonich, Plato's Utopia Recast, 263; M. Sassi, 'The Self, the Soul and the Individual in the city of the Laws', Oxford Studies in Ancient Philosophy 35 (2008) 125-48, 131; Wilburn, 'Akrasia', 29, and S. Sauvé-Meyer, trans. and comm., Plato's Laws 1 and 2 (Oxford: Clarendon Plato Series, 2015) 175, who takes the expression as 'the general category of non-rational motivation'.
} 


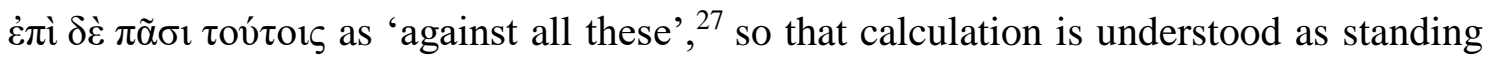
in opposition to the non-rational.

Because this passage has been introduced as a way of elucidating what selfcontrol is, conflict must necessarily be present in it. It should be noted, however, that here it is pleasure and pain, confidence and fear that are explicitly characterised as opposed, not the rational and the non-rational. The dual form employed by the Athenian ( $\dot{\varepsilon} v \alpha v \tau i ́ \omega)$ indeed suggests that pleasure and pain are operative and oppose each other on the same level, while calculation comes into play only on a second level to judge the conflicting forces. ${ }^{28}$ The enclosure of opposition and thus of conflict within the non-rational sphere

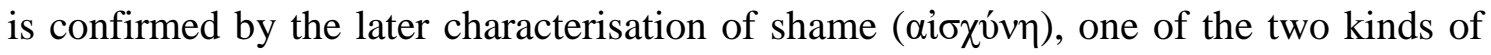
fears identified by the Athenian, as 'opposed ('̇vavtíos) to pain and other fears, but also opposed (Évavtíos) to the most numerous and powerful pleasures', as well as to 'the

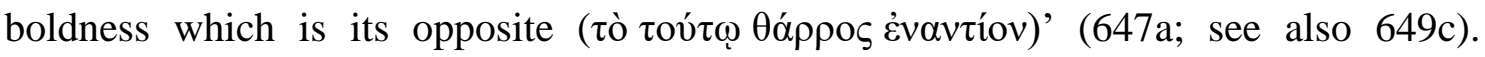
Opposition appears as a characteristic that belongs to the non-rational phenomena of the soul. Finally, the fact that these psychic forces are called 'counsellors ( $\sigma v \mu \beta \sigma v i \lambda \omega)$ ' (644c), also in the dual, suggests that their activity is judged by an authority that by definition has to be above them in dignity, a point adequately captured by Griffith in the political metaphor of his translation, 'presiding over all this'.

The superior dignity of calculation has important implications for our present discussion. By framing the relation between calculation and the non-rational sphere as one of reflection and not one of opposition, the Athenian has implicitly stated that calculation is 'the best part' in the soul, the one which ought to achieve victory if individuals are to rule themselves. But now some questions arise. Isn't the stress on the need for the victory of calculation precisely what Clinias' conflict model of virtue would require? How does the harmony model enter this picture?

To understand how the Athenian's argumentative strategy is at work in this passage we must take into account the crucial fact that calculation is not depicted as opposing other elements in psychic conflict. This should not be taken to mean that

\footnotetext{
${ }^{27}$ Laws 1 and 2, 40; cf. also 176.

${ }^{28}$ Recently, Giménez, 'La psicología moral', 147-9, and Pfefferkorn, 'Shame', 265, have also emphasised that conflict proper is enclosed within the non-rational sphere of the soul, so that the intervention of calculation (which is never called an 'opposite') in it can only happen through association with an already conflicting force.
} 
calculation is altogether unrelated to the non-rational conflict, however. By judging what is better or worse in the opposing non-rational elements, calculation allies with the elements it judges to be better and thus opposes the others. But this participation is not a direct one, as it were, and should rather be understood as a mediated or indirect kind of participation through association. ${ }^{29}$ Therefore, the Athenian's exclusion of calculation from non-rational psychic conflict is qualified: calculation doesn't partake in conflict in the same sense as the non-rational elements.

The fundamental reason for this qualified exclusion of calculation from psychic conflict will become clear in the image of the puppet. It is the forceless nature of calculation which makes it impossible for it to partake directly in the conflict. This is the crucial turning point in which the Athenian will effectively integrate and subordinate psychic conflict (and the courage needed to be victorious in it) within the harmony model of virtue. The nature of calculation ultimately explains why the conflict model of virtue is unable to give an adequate account of education and of virtue. I will now attempt to show how the Athenian makes this point in the image of the puppet.

\section{The two Models of Virtue in the Image of the Puppet}

Once the Athenian has given his first sketch of the moral psychology involved in education and in the phenomenon of self-rule, his Dorian interlocutors confess that they haven't understood it. 'I'm having a bit of difficulty following this' (644d), says Clinias. The Athenian offers the puppet image as a way of clarifying what he meant with the first sketch. Here is how he introduces the image:

Let's take the view that each one of us living creatures is a puppet belonging to the gods, put together either as their toy or for some serious reason - that being something we don't know. What we do know is that these feelings $(\pi \dot{\alpha} \theta \eta)$ we have are like tendons or strings inside us, drawing us but pulling in opposite directions, towards opposite actions, and in fact the demarcation line between human goodness and badness lies here. According to this account ( $\lambda$ óyos), there is one of the pulls which each of us must always follow, never letting go of that string, and resisting the other tendons; this pull comes from the golden and sacred string of

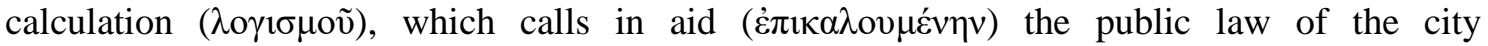

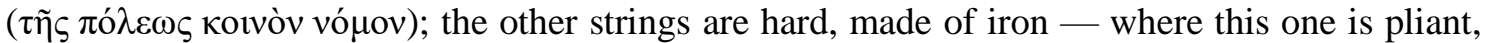
being made of gold - but resembling various kinds of things; and we must always cooperate with the finest pull, which is from the law, since calculation, fine as it is, is also gentle and non-

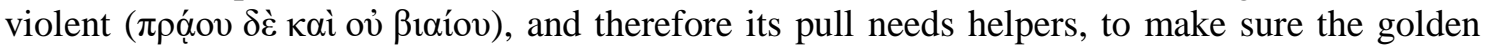
type of string within us overcomes (vikã ) the other types. (644d-45a)

\footnotetext{
${ }^{29}$ Cf. Giménez, 'La psicología moral', 155.
} 
One notices a tension between the elements of the comparison. We, living beings that move themselves, are said to be like artefacts, which notoriously don't have in themselves the principle of their own movement, and in this respect aren't like us. As Leslie Kurke has pointed out ${ }^{30}$, however, the puppet is no mere artefact, but one that gives the illusion of self-movement and thus seems to be alive. By way of its appearance of self-movement, the puppet seems to be like us, living beings. Inversely, we seem to be like puppets insofar as the strings of pleasure and pain (our pathē) make us move mechanically, in such a way that our actions are not the result of reflective rational activity. In the image as in the passage that introduces it $(644 \mathrm{c}-\mathrm{d})$, these non-rational

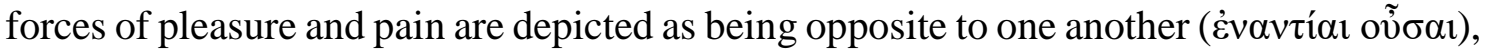
suggesting again that they are the conflicting forces that pull the individual towards

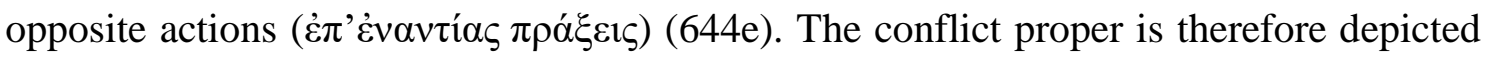
once more as arising within the non-rational sphere of the soul.

As long as no rationality arises, human beings are bound to be 'yanked around, ${ }^{31}$ drawn as they are by the ferrous forces of pleasure and pain. Calculation enters the picture to remedy the blindness of the movement thus produced by the non-rational conflict. Its task is once again presented as the determination of what is best and worse in the nonrational forces. ${ }^{32}$ By its very nature, this rational activity can hardly be on the same level as the blind conflict between pleasure and pain, so that the puppet image seems to confirm Griffith's interpretation of calculation as 'presiding over' the non-rational forces in the introductory sketch offered by the Athenian. Here the superiority of calculation is signalled by the adjectives 'golden' and 'sacred': it is made of a different material, it has a divine status. Granted, it is one of the pulls ( $\mu 1 \tilde{\alpha} \ldots \tau \tilde{\omega} \nu \tilde{\varepsilon} \lambda \xi \varepsilon \omega v)$ which define the puppet's movement, indeed the one it ought to follow, but it crucially isn't one of the

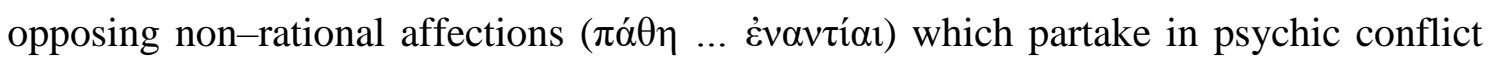
proper (644e). The point is crucial: calculation is never called enantios to anything in Book 1, while the non-rational forces are repeatedly depicted as opposed to one another. Calculation rather enters the conflict indirectly, by allying with the better non-rational

\footnotetext{
${ }^{30}$ L. Kurke, 'Imagining chorality: wonder, Plato's puppets, and moving statues', in A. Peponi, ed., Performance and Culture in Plato's Laws (New York: Cambridge University Press, 2013) $123-70,126 \mathrm{ff}$.

${ }^{31}$ Annas, Virtue and law, 88

${ }^{32}$ I therefore agree with D. Frede, 'Puppets on strings', 119, that calculation is not a 'force' that actually struggles against others in the conflict inside the puppet, but the rational capacity of shaping and giving moral value to the non-rational forces.
} 


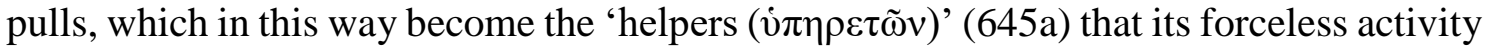
is said by the Athenian to be in grave need of.

\section{Calculation's Helpers: Law and Shame}

This touches on the central problem for the puppet, namely that calculation, by

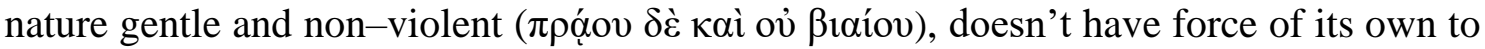
resist the ferrous non-rational forces. Furthermore, it is possible that it produces a false judgment about the moral value of the ferrous strings in a given situation. The image consequently goes on to explain both how to ensure that calculation is able to reach a true judgment, and how to ensure that this judgment is followed by the individual. ${ }^{33}$ This is the task of law. Because calculation is both forceless and prone to error, it must call into

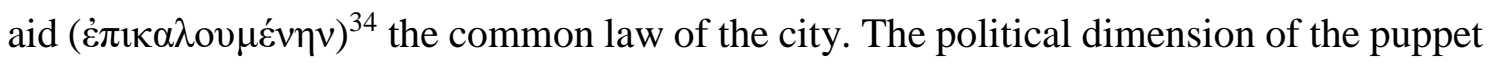
image recalls the one found in the Athenian's initial sketch, the law being called 'common (Kovvóv)' in both cases. As Schofield argues, law is common in the sense that it represents an intersubjective framework of reference for the rational activity of the individual, a framework that supports the truth of the judgment of calculation. ${ }^{35}$ Moreover, by bringing the weight of the sanctions of the community into the decisive moment of acting in accordance with this judgment, law helps ensure that the individual effectively follows it. Through the connection with the common framework of reference of the law, then,

\footnotetext{
${ }^{33}$ On the difficult problem of akrasia in the Laws see Bobonich, Plato's Utopia Recast, 246-66; L. Gerson, Knowing Persons: A Study in Plato (Oxford: Oxford University Press, 2003) 265-70, 266; C. Kahn, 'From Republic to Laws. A Discussion of Christopher Bobonich, Plato's Utopia Recast', Oxford Studies in Ancient Philosophy 26 (2004) 337-62; and Wilburn, 'Akrasia', 26, who uniquely among commentators denies that Plato contemplates the possibility of acratic action in the Laws, defending instead that the self-rule or lack of it spoken of in the image of the puppet refer to general states of the soul.

${ }^{34}$ Following A. Nightingale, 'Plato's lawcode in context: rule by written law in Athens and Magnesia', Classical Quarterly 49 (1999) 100-22, 104 n.13, Griffith and Schofield, Plato, the Laws, 59 read غ̇ $\pi \iota \kappa \alpha \lambda o v \mu \varepsilon ́ v \eta v$ in the middle voice, and translate it as 'calling into aid'. This goes against the more usual translation of the passage, which reads the participle in the passive voice

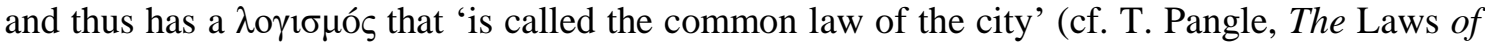
Plato [Chicago: University of Chicago Press, 1988] 25; see also Sauvé-Meyer Laws 1 and 2, 401 , who however then supports the Griffith translation in S. Sauvé-Meyer, 'Review of Griffith and Schofield 2016', Bryn Mawr Classical Review 2018.03.49).

${ }^{35}$ The interpretation given here of the role of law follows closely that of Schofield, 'Plato's Marionette', 140-146.
} 
individuals go beyond their own powers, adopting a common, more universal point of view in their deliberations and actions.

The reliance of calculation on law points to one concrete way in which the former allies with the better non-rational elements to overcome the worse elements in psychic

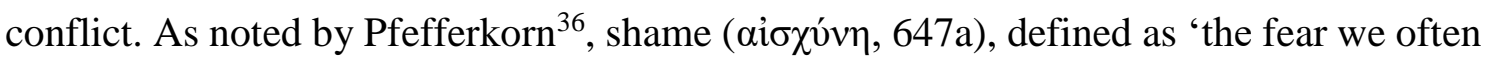
have of what people think' (646e) of our words and actions, is construed by the Athenian as the 'social emotion' that corresponds functionally to the role attributed to law in the puppet image. For shame of being reproached by the community, the individual follows the law. In this sense, the Athenian depicts shame precisely as the kind of non-rational force that supports calculation in order to resist the worse non-rational forces of pain, fear, desire, pleasure, and boldness, forces to which shame is naturally opposed (see 647a ff.). By its very nature, then, shame becomes the basis for the Athenian's educational symposia. The wine taken in these events intensifies the non-rational elements of the young citizen's souls while weakening the rational element, so that with the help of shame they train themselves in resisting the various non-rational forces that get strengthened (645d ff.). According to the Athenian, this training helps bring about the correct organisation of the conflicting non-rational elements. The definition of education as the correct conformation of the conflicting non-rational forces towards consonance with calculation is therefore seen here in full operation.

\section{The Double Purpose of the Puppet Image}

If this interpretation of the puppet image is correct, then we can make good sense of its closing section, in which the Athenian reminds us that the image purported to explain both the phenomenon of self-mastery and education (cf. $645 \mathrm{~b}-\mathrm{c}$ ). The nature of self-rule has been cleared up by showing that the golden cord overcomes (vikã 645a) the ferrous non-rational forces when action follows the judgements of calculation, the 'best part in us'. As we have seen, this victory is achieved by calculation indirectly, by means of its alliance with non-rational forces such as shame, which partake directly in the

\footnotetext{
36 'Shame', 258 n. 12. The point had been previously hinted at by Schofield, Plato, the Laws, 59 n. 43, but Pfefferkorn offers a very detailed analysis of the way in which the 'secondary emotions' (265) of anticipation ally with calculation to oppose the 'primary emotions' of pleasure and pain proper.
} 
conflict, oppose the worse non-rational elements and help the citizen take the upper hand in the battle against his own pleasures (cf. 647c).

This points in turn to the significance of the image for education. It is through educational institutions that the alliance between calculation and the better non-rational forces is achieved. But the very nature of education, which strives towards psychic consonance, frames the victory of calculation within the wider educational aim at consonance itself, that is to say, within the harmony model of virtue. Education makes use of conflict by procuring the alliance between calculation and the better non-rational forces, but it significantly doesn't take conflict to be the natural and perpetual state of the soul, as the conflict model of virtue does. Instead, it envisages the eventual appeasement of conflict in a non-violent way that brings about a consonant state of soul.

Even if the conflict model of virtue is undoubtedly present in the puppet image, then, the image is ultimately concerned with illuminating the moral psychology for educational institutions based on the harmony model of virtue, the first instance of which is the Athenian's directed symposia. This is signaled in the image itself by way of a key terminological resonance. As noted by Sauvé-Meyer herself ${ }^{37}$, the talk about 'grasping

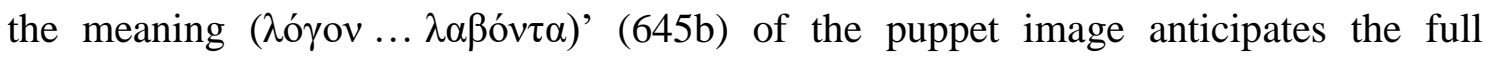
definition of the harmony model of virtue, where the expression is used to describe both

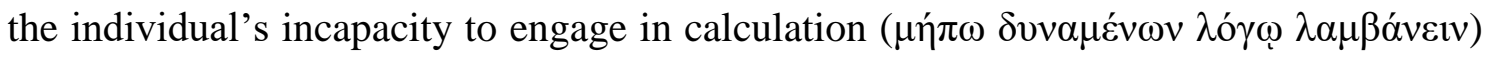

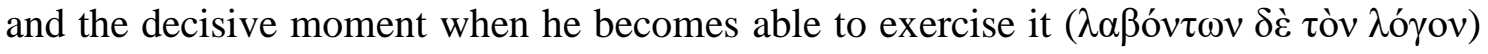
(653b). Grasping the meaning of the image amounts to exercising calculation, insofar as the dynamics of the pulls in the soul begin to be understood. This is taken by the Athenian to be the final step in education towards consonance, the step that completes the formation of a perfect ( $\tau \varepsilon \dot{\lambda} \varepsilon$ ov $643 \mathrm{e}$ ) citizen. The fact that this final educational step in the harmony model of virtue is described by the Athenian with the vocabulary of the image of the puppet seems to me to provide further confirmation that the image is mainly concerned with illuminating the nature of education.

\section{Conclusion}

This account helps understand the Athenian's strategy in persuading his Dorian interlocutors of the superiority of the psychological version of the harmony model of

\footnotetext{
${ }^{37}$ Laws 1 and 2, 185.
} 
virtue. The Athenian announced this strategy by proposing that the old men take courage as the paradigm for understanding the three higher parts of 'the whole of virtue' (632e). To carry out this project, the Athenian agreed with a qualified version of Clinias' allpervasive conflict thesis, recognising that political and psychological conflict in fact constitute the basis for any consonance-oriented legislative and educational project. Moreover, the Athenian also agreed that victory in conflict should be achieved by 'the best part in us'. I see these argumentative steps as explaining the Athenian's continued use of the language of the conflict model of virtue throughout Book $1 .^{38}$

However, the Athenian also showed in the image of the puppet that calculation, the best part in us, is essentially 'soft and forceless', so that it can be victorious in conflict only by means of its alliance with the non-rational 'helpers'. This is the point in which the Athenian will not agree with Clinias' conflict model anymore, for the alliance between calculation and the better non-rational forces, an alliance initially operated through education, essentially aims at psychic consonance. The state of conflict is indeed the starting point for education, but it is neither natural nor perpetual, and the final aim is to dissolve it in the consonant ensemble. By first accepting that psychic conflict plays a significant role in education and then showing that education itself aims at producing consonance out of the initial state of conflict, the Athenian effectively subordinates the state of conflict within the harmony model of virtue. This subordination is operative in the directed symposia he proposes to his interlocutors, educational institutions presented as a kind of Dorian training aiming at courage but that, nevertheless, ultimately aim at producing consonance in the souls of the citizens.

The Athenian thus qualifiedly integrates some central tenets of the conflict model of virtue within the harmony model, while doing away with the conflict model itself and with its grim view of human nature. From the beginning of Book 2 onwards, the conflict model consequently becomes 'obsolete' ${ }^{39}$, its language disappearing almost completely from the discussion. The Dorian elders seem to have understood that the Athenian has presented them with a better conception of virtue, one which takes conflict into account but also amplifies the scope of education to aim at the 'whole of virtue' in the consonant soul. As a result, after the Athenian's full formulation of the harmony model of virtue,

\footnotetext{
${ }^{38}$ This continued use has lead Sauvé-Meyer to speak of the 'persistence of the CONFLICT model' ('Self-Mastery', 107).

${ }^{39}$ The term is Schofield's ('Plato's Marionette', 149).
} 
Clinias explicitly expresses his agreement with it: 'Yes, my friend. The things you said earlier about education seemed to us to be correct - and the same goes for the things you've just been saying' (653c). The Athenian is now able to undertake further elucidations on the nature of education, and the Dorian elders present almost no resistance to the proposals he will make. If then, as Pfefferkorn remarks, 'conflict and the necessity to find an agreement are reflected in the lively discussion between the three characters ${ }^{, 40}$, Clinias' response could be taken to mean that an agreement on the nature of virtue and education has indeed been reached.

Diego García Rincón Ludwig-Maximilians-University

\section{Bibliography}

Annas, J. Virtue and law in Plato and Beyond (Oxford: Oxford University Press, 2017).

Belfiore, E. 'Wine and the Catharsis of Emotions in Plato's Laws', Classical Quarterly 36/2 (1986) 421-37.

Bobonich, C. Plato's Utopia Recast: His Later Ethics and Politics (Oxford: Clarendon Press, 2002).

Folch, M. The City and the Stage: Performance, Genre, and Gender in Plato's Laws (Oxford: Oxford University Press, 2015).

Fossheim, H. 'The Prooimia, Types of Motivation, and Moral Psychology', in C. Horn, comp., Platon: Gesetze - Nomoi (Sankt Agustin: Academia Verlag, 2013) 87-104.

Frede, D. 'Puppets on strings: Moral Psychology in Laws Books 1 and 2', in C. Bobonich, ed., Plato's Laws: A Critical Guide (Cambridge: Cambridge University Press, 2010) 108-26.

Gaudin, C. 'Humanisation de la Marionette. Plat. Leg. I 644c-645d; VII 803c-804c', Elenchos 23 (2002) 271-95.

Gerson, L. Knowing Persons: A Study in Plato (Oxford: Oxford University Press, 2003) 265-70.

Giménez Salinas, J. A. 'La psicología moral de la marioneta. Conflicto y acuerdo en las Leyes de Platón', Ideas y Valores 68.171 (2019) 137-159.

Griffith, T. trans., and M. Schofield, ed., Plato: The Laws (Cambridge: Cambridge University Press, 2016).

Jorgenson, C. The Embodied Soul in Plato's Later Thought (Cambridge: Cambridge University Press, 2018).

40 'Shame', 260. 
Jouët-Pastré, E. Le jeu et le sérieux dans les Lois de Platon (Sankt Augustin: Academia Verlag, 2006).

Kahn, C. 'From Republic to Laws. A Discussion of Christopher Bobonich, Plato's Utopia Recast', Oxford Studies in Ancient Philosophy 26 (2004) 337-62.

Klosko, G. The Development of Plato's Political Theory (Oxford: Oxford University Press, 2006).

Kurke, L. 'Imagining chorality: wonder, Plato's puppets, and moving statues', in A. Peponi, ed., Performance and Culture in Plato's Laws (New York: Cambridge University Press, 2013) 12370.

Nightingale, A. 'Plato's lawcode in context: rule by written law in Athens and Magnesia', Classical Quarterly 49 (1999) 100-22.

Pangle, T. The Laws of Plato (Chicago: University of Chicago Press, 1988).

Pfefferkorn, J. 'Shame and Virtue in Plato's Laws: Two Kinds of Fear and the Drunken Puppet', in L. Candiotto and O. Renault, eds., Emotions in Plato (Leiden/Boston: Brill, 2020) 252-269.

Sassi, M. 'The Self, the Soul and the Individual in the city of the Laws', Oxford Studies in Ancient Philosophy 35 (2008) 125-48.

Sauvé-Meyer, S. 'Review of Griffith and Schofield 2016', Bryn Mawr Classical Review 2018.03.49.

Sauvé-Meyer, S. 'Self-Mastery and Self-Rule in Plato's Laws', in D. Brink, S. Sauvé-Meyer, and C. Shields, eds., Virtue, Happiness, Knowledge: Themes from the Work of Gail Fine and Terence Irwin (Oxford: Oxford University Press, 2018) 97-109.

Sauvé-Meyer, S. trans. and comm., Plato's Laws 1 and 2 (Oxford: Clarendon Plato Series, 2015).

Schofield, M. 'Plato's Marionette', Rhizomata 4/2 (2016) 128-53.

Schofield, M. 'The Laws' Two Projects', in C. Bobonich, ed., Plato's Laws: A Critical Guide (Cambridge: Cambridge University Press, 2010) 12-28.

Wilburn, J. 'Akrasia and Self-Rule in Plato's Laws', Oxford Studies in Ancient Philosophy 43 (2012) 25-53.

Zuckert, C. Plato's Philosophers: The Coherence of the Dialogues (Chicago: University of Chicago Press, 2009). 